\title{
Geology of the Aftabrou Polymetallic Deposit, Saveh, Iran
}

\author{
Akram Sabzian 1 , Fariborz Masoudi ${ }^{*}$, Hooshang Asadi-Harooni ${ }^{3}$, Mohammad-Hashem Emami ${ }^{4}$, \\ Nima Nezafati ${ }^{1}$
}

${ }^{1}$ Department of Geology, Science and Research Branch, Islamic Azad University (IAU), Teheran, Iran

${ }^{2}$ Faculty of Earth Sciences, Shahid Beheshti University, Evin, Tehran, Iran

${ }^{3}$ Department of Mining Engineering, Isfahan University of Technology, Isfahan, Iran

${ }^{4}$ Department of Geology, Islamshahr Branch, Islamic Azad University, Teheran, Iran

Email: *drfmasoodi@gmail.com

How to cite this paper: Sabzian, A., Masoudi, F., Asadi-Harooni, H., Emami, M.-H. and Nezafati, N. (2017) Geology of the Aftabrou Polymetallic Deposit, Saveh, Iran. Open Journal of Geology, 7, 978-999.

https://doi.org/10.4236/ojg.2017.77066

Received: January 25, 2017

Accepted: July 18, 2017

Published: July 21, 2017

Copyright (C) 2017 by authors and Scientific Research Publishing Inc. This work is licensed under the Creative Commons Attribution International License (CC BY 4.0).

http://creativecommons.org/licenses/by/4.0/

\begin{abstract}
Aftabrou polymetallic prospect is located at the contact of Oligo-Miocene calcalkaline granodioritic to dioritic and Eocene andesitic to basaltic volcanic complex in middle section of Urumiyeh-Dokhtar volcanic arc in NW of Saveh city. Petrographic study indicated that the volcanic rocks are mostly: lava and tuff. Composition of lavas is mainly andesite and tuffs are mainly composed of dacite to rhyodacite. Major phenocrysts in these rocks are plagioclase, clinopyroxene, hornblende and opac minerals. Petrographic and geochemical studies indicated an I-type granitoid and, calcalkaline magmatism associated with continental margin of subduction zone. This study determined three mineralization subzones of $0.2 \%-5.3 \% \mathrm{Cu}, 0.02-1.31 \mathrm{ppm} \mathrm{Au}$ and $1.2 \%$ $3.9 \% \mathrm{Zn}$. Fluid inclusion studies on quartzic veins associated with magmatism, demonstrated that homogenization temperatures of this mineralization fluid are between $170^{\circ} \mathrm{C}$ to $330^{\circ} \mathrm{C}$, the salinity of the system is between 11.7 to 23.5 weight percent, density of this fluid is $0.8-1.1 \mathrm{~g} / \mathrm{cm}^{3}$ and is occurred in depth of less than $1800 \mathrm{~m}$ of surface. Fluid inclusion studies suggested that formation of mineral deposit is simple cooling and mixing with atmospheric water and type of Aftabrou deposit is IOCG. In this base, it is assumed that this IOCG mineralization is occurred associate with magmatism that is formed as a result of Neo-Tethys oceanic subduction beneath the Central Iran zone which is replaced in the Orumieh-Dokhtar magmatic arc.
\end{abstract}

\section{Keywords}

Aftabrou, Polymetallic Mineralization, Calcalkaline, Fluid Inclusion, IOCG Deposit 


\section{Introduction}

The UDMA is a frontier region with high mineral potential [1] [2] [3] [4] for which a comprehensive and detailed research is required. Aftabrou is polymetallic deposit [5] [6] that formed in contact of calcalkaline volcanic-plutonic and alkaline sub-plutonic complex in central Iran on Uramieh-Dokhtar magmatic belt. It is located on northwestern of Saveh geological map of scale 1:100,000, in the province of Markazi, $\sim 60 \mathrm{~km}$ northwest of the city of Saveh (Figure 1).

Aftabrou pluton containing of two part, plutonic and sub plutonic rocks [7] that by relatively age-dating, sub plutonic rocks are youngest unit in studied area [8]. Plutonic rocks are diorite and granodiorite but subputonic is diorite that both of them are formed from I-Type magma and related to continental margin of subduction zone [7]. Although, volcanic-plutonic-hosted-related polymetallic gold and/or copper and/or Zinc mineralization are known at Dalli [2] and Kahang (Figure 1), research on geology and mineralization of Aftabrou is few. [5] [6] [9]. Yet, geochemical properties and style of mineralization, tenor of metal elements, properties of ore fluid, type of mineralization and more important, the relationship between mineralization and magmatism in Aftabrou area, are not studding, completely and exactly. In this study, we will consider above items, exactly.

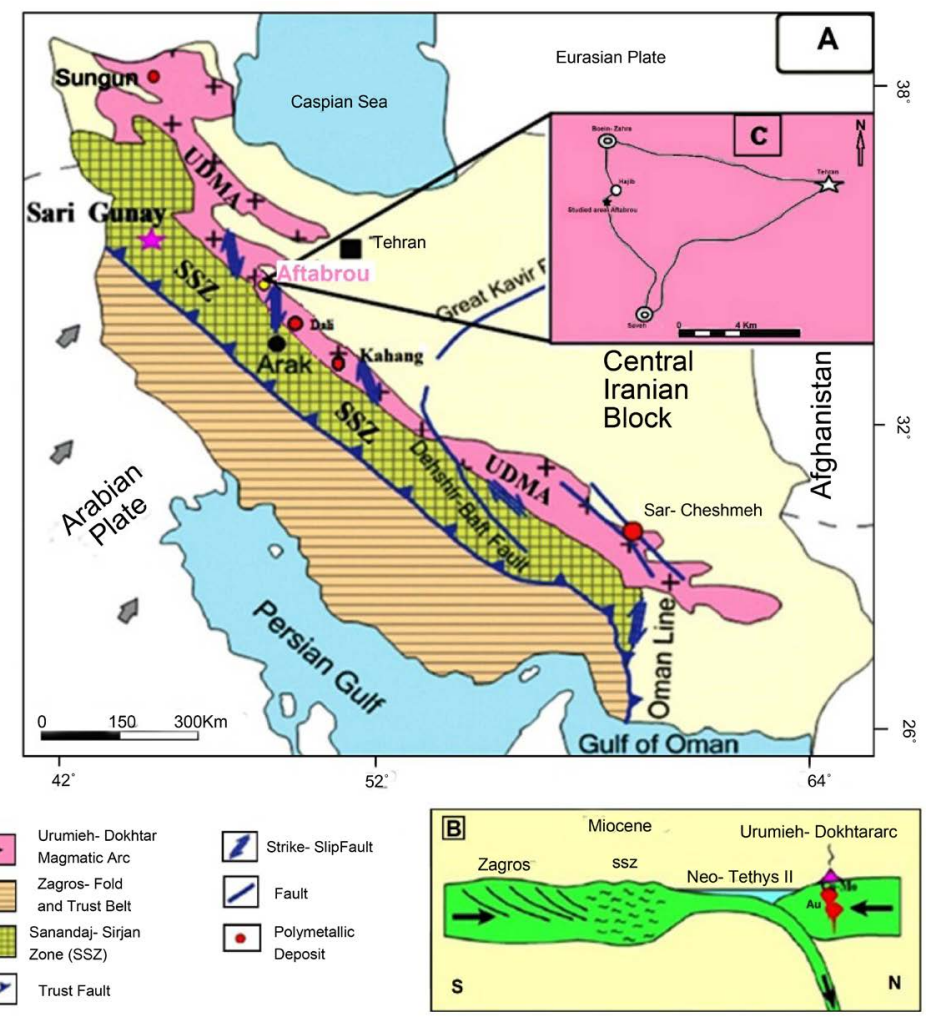

Figure 1. (A) Map showing the study area in UDMA (Uramieh-Dokhtar Magmatic Arc) and other major geological subdivisions of this magmatic belt of Iran (modified from Zarasvandi et al., 2005). (B) Subduction of Neo-Tethys Ocean to the north beneath central Iran, giving rise to the formation of UDMA and mineralization (modified after Glennie, 2000). (C) Available roads to Aftabrou. 


\section{Study Area}

The study area is a sparsely vegetated, semi-arid, mountainous region located in central part of the UDMA in Iran (Figure 1). The UDMA is the most important volcanic arc of Iran that extends about $2000 \mathrm{~km}$ in an N-SE direction in the central part of the Tethyan metalorganic belt. This arc hosts volcanic and plutonic rocks with calcalkaline magma genesis, mainly that this is hosts some world class polymetallic mineralization deposits such as Sar-Cheshmeh, Songun, Meiduk, Kahang, Darezar, Drrreh-Zerreshk and Dalli [2] [10]. Most of these deposits are related to calcalkalin magmatism, mainly and sometimes to alkaline-calcalkaline magmatism [7] [11] and located in the southeast or northwest of the UDMA belt. The central UDMA is a frontier region with high mineral potential [1] [2] [3]. Aftabrou prospect is prominent polymetallic system in the central UDMA [2] [9].

\section{Geologic Setting of Aftabrou}

The Aftabrou polymetallic deposit is hosted by a Miocene [4] plutonic and sub plutonic rocks that outcrops of middle Eocene [8] volcanic complex that forms a range of small hills in an area $4 \mathrm{~km}$ across, flanked to the east and southeast by shallowly sloping tuff deposits (Figure 2). Mineralization is seen mainly, in

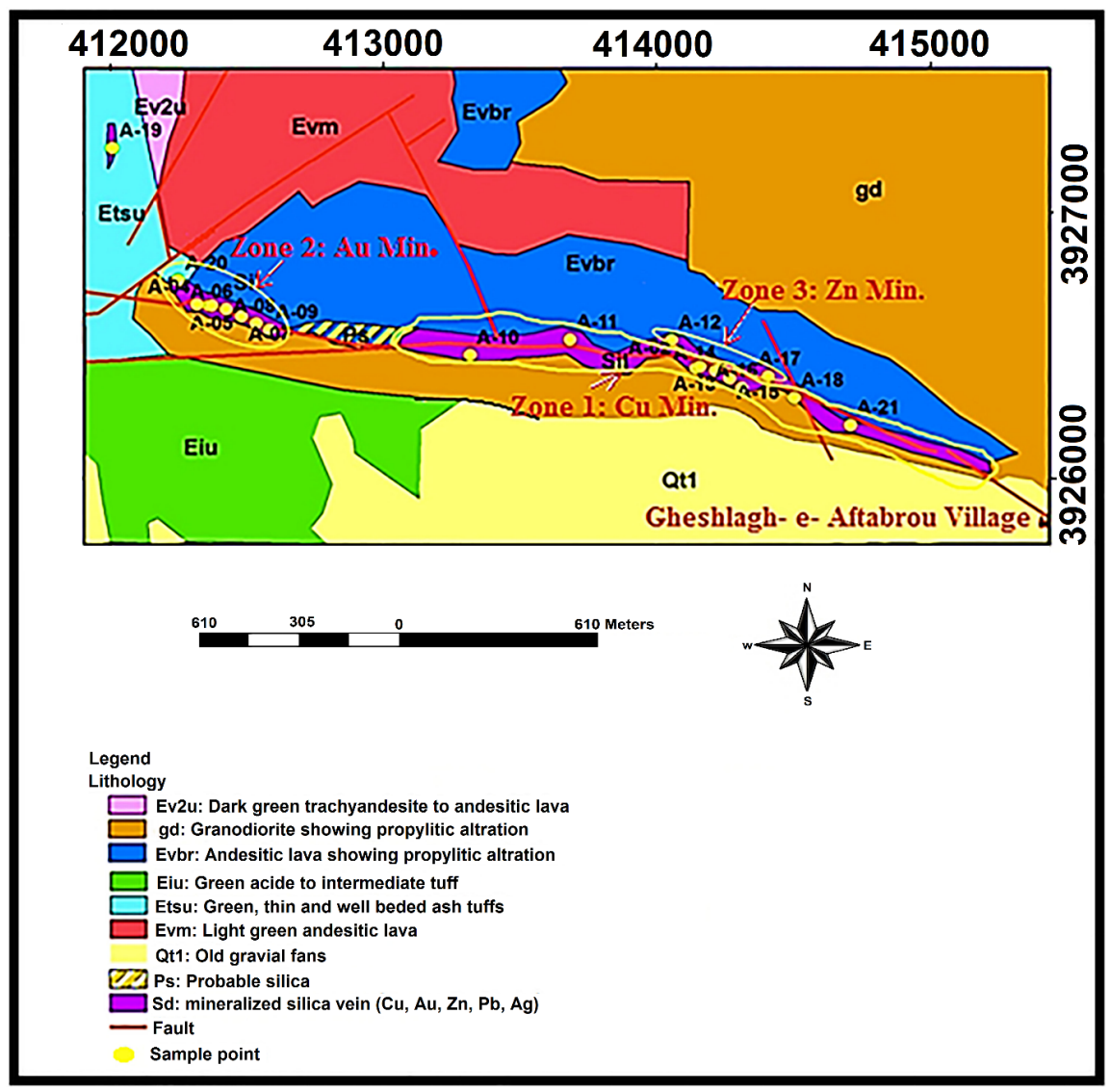

Figure 2. Geologic map of the Aftabrou area compiled from mapping by H. Asadi Harooni (2014). 
breccial zone between volcanic and plutonic-sub plutonic rocks. This breccial zone is $2500 \mathrm{~m} \times 100 \mathrm{~m}$. The margins of the complex to the south and southeastern slope gently below Quaternary alluvial deposits, such that precise outcrop limits are soft to constrain. Sub plutonic rocks is surrounded plutonic rocks and is least volume in this area [7]. All of those units are shown in one background of this area in Figure 3(a).

\section{Research Methods}

Our researches in this study consist of two main parts. Once part: study of fresh volcanic rocks. After collecting and verifying the information, reports and maps of the area, check field study and survey in the various stages, select about 100 samples of the fresh volcanic rocks. The 42 samples that have lowest degree of weathering select for preparation thin sections for petrography study that do with Olympus Microscope, model BH-2 in Isfahan University. After microscopic studies for geochemical studies 12 samples of fresh igneous rocks from the Aftabrou volcanic complex were collected for whole-rock geochemical analysis. All of them were analyzed by ICP-MS method and 8 samples of them were analyzed by XRF method. Second part. study of weathered rocks related to mineralization. For this purpose, unsystematic lithogeochemical samples that were altered and mineralized from breccia and silicified zone in contact of volcanic and plutonicsub plutonic rocks and toward volcanic, plutonic-sub plutonic, are selected. These studies are done with preparation polish and thin section in Isfahan University.
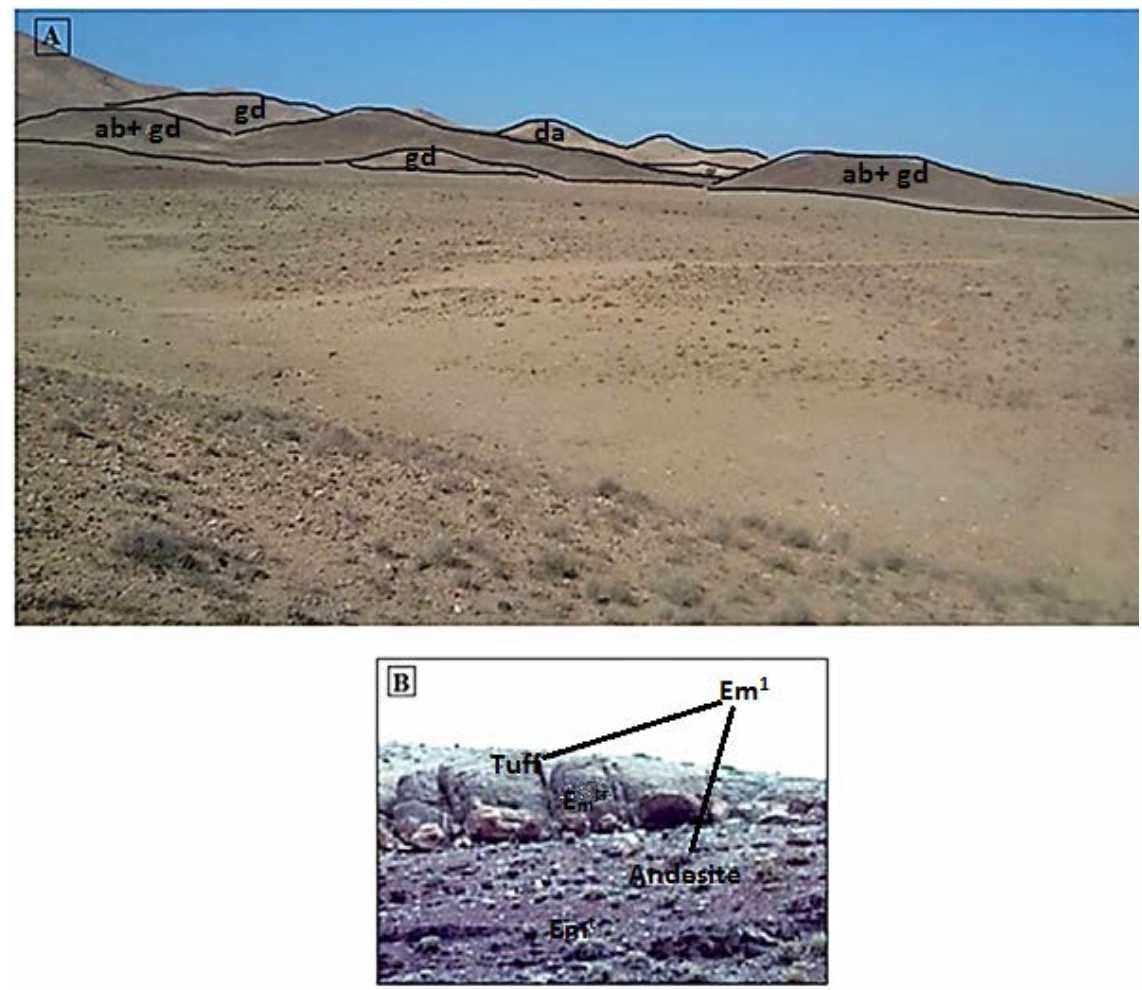

Figure 3. (A) Background of all rock units in Aftabrou area, (B) Andesitic tuff convert to lava, laterally. 
In order to apply geochemical mineralization study, 22 unsystematic lithogeochemical samples were analyzed by XRF method. Results of this analyze is shown in Table 1 and Table 2. All of these analysis (in part 1 and 2) done in Zar Azma laboratory in Tehran. In order to determine mechanism of forming mineral and type of mineralization study of fluid inclusion of mineralization is done in Isfahan University. Result of this analyze are listed in Table 3. Finally, these analyses were processed by using Excel, GCDKit, Minpet, and Igpet programs.

\section{Petrography of Aftabrou Rocks}

Rocks in Aftabrou area are 3 groups of volcanic, plutonic and sub plutonic, that volcanics are highest volume and oldest, while, sub plutonics are lowest volume and youngest.

Table 1. Chemical analisis results for volcanic rocks.

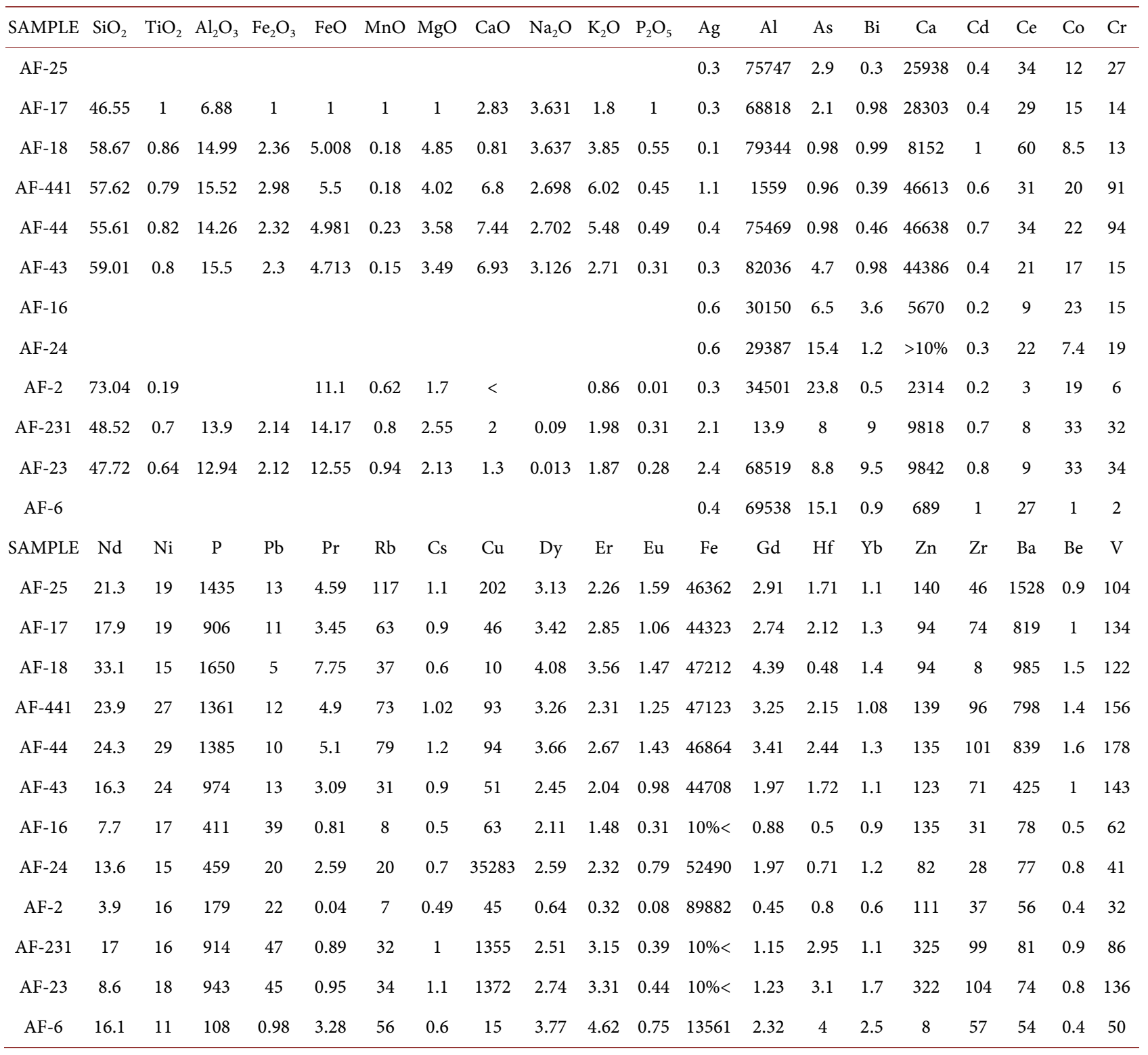


Table 2. Some results of unsystematic lithogeochemical analyze of altered and mineralized samples.

\begin{tabular}{|c|c|c|c|c|c|c|c|c|}
\hline N.sample & $\mathrm{Au}$ & $\mathrm{Cu}$ & $\mathrm{Zn}$ & $\mathrm{Ag}$ & As & $\mathrm{Fe}$ & $\mathrm{Mn}$ & $\mathrm{Pb}$ \\
\hline K1292 & & 2425 & 103 & 0.35 & 2.6 & 104156 & 2431 & 12 \\
\hline K1293 & 33 & 5484 & 142 & 0.31 & 3.2 & 90975 & 944 & 21 \\
\hline K1294 & 320 & 280 & 208 & 0.8 & 2.6 & 99656 & 5689 & 127 \\
\hline K1301 & 539 & 136 & 348 & 0.37 & 4.9 & 98021 & 2925 & 28 \\
\hline K1302 & 28 & 5603 & 420 & 1.7 & 2.9 & 102754 & 3957 & 548 \\
\hline K1303 & 1306 & 151 & 38 & 0.54 & 4 & 59869 & 677 & 41 \\
\hline K1304 & 296 & 244 & 142 & 4.5 & 3.3 & 78579 & 1311 & 619 \\
\hline K1305 & 445 & 150 & 78 & 12.3 & 3.3 & 64114 & 2239 & 9440 \\
\hline K1306 & 19 & 336 & 84 & 0.52 & 4.2 & 115190 & 1011 & 32 \\
\hline K1307 & 82 & 52729 & 304 & 0.29 & 3.4 & 130546 & 1273 & 17 \\
\hline K1308 & 98 & 1112 & 19211 & 1 & 3.2 & 86549 & 4223 & 50 \\
\hline K1309 & 57 & 1514 & 26890 & 7.5 & 5.1 & 56519 & 4181 & 360 \\
\hline K1310 & 394 & 5353 & 131 & 0.28 & 19.9 & 102648 & 2939 & 8 \\
\hline K1311 & 43 & 391 & 91 & 0.31 & 3.7 & 81448 & 2278 & 7 \\
\hline K1312 & 164 & 1263 & 218 & 0.39 & 12.7 & 134215 & 3568 & 12 \\
\hline K1313 & 37 & 8917 & 153 & 0.36 & 3.5 & 86576 & 1653 & 6 \\
\hline K1314 & 16 & 61 & 181 & 0.36 & 3.8 & 112621 & 3095 & 7 \\
\hline K1315 & 117 & 13334 & 275 & 0.8 & 62.1 & 141490 & 4524 & 28 \\
\hline K1316 & 40 & 786 & 43 & 0.49 & 292 & 113483 & 1247 & 16 \\
\hline K1317 & 33 & 35503 & 266 & 0.54 & 41.7 & 92719 & 1319 & 21 \\
\hline K1318 & 22 & 25025 & 217 & 0.37 & 5.1 & 30932 & 1103 & 12 \\
\hline K1319 & 5 & 60 & 97 & 0.29 & 2.4 & 11424 & 2067 & 15 \\
\hline
\end{tabular}

Volcanic rocks in Aftabrou are lava and tuff. The volume of lavas is more than tuffs. In more times lavas convert to tuffs, laterally (Figure 3(b)). Tuffs have dasitic composition and mainly destructal texture (Figure 4(a), Figure 4(b)). Lavas have andesitic composition and mainly porphyric texture (Figure 4(c), Figure $4(\mathrm{~d})$ ).

Plutonic rocks are granodiorite to diorite [7] [11]. Sub plutonic rocks, only, are included diorite [7].

\section{Igneous Geochemistry of the Aftabrou Rocks}

Calcalkaline, I-type magma formed plutonic rocks and alkaline magma formed sub plutonic rocks in Aftabrou area [7]. In this study, at first, we consider nature and type of magma former volcanic rocks.

\subsection{Sample of Volcanic Rocks}

12 samples of fresh igneous rocks from the Aftabrou volcanic complex were collected for whole-rock geochemical analysis. All of them were analyzed by ICP- 
Table 3. Data from micro thermometry of fluid inclusion of polymetallic deposit of Aftabrou deposit.

\begin{tabular}{|c|c|c|c|c|c|c|c|}
\hline $\mathrm{P}, \mathrm{PS}, \mathrm{S}$ & $\mathrm{NaCl}$ (\%wt.) & $\begin{array}{c}\text { Type of } \\
\text { homogenition }\end{array}$ & $\operatorname{Th}\left({ }^{\circ} \mathrm{C}\right)$ & $\operatorname{Tlm}\left({ }^{\circ} \mathrm{C}\right)$ & $\operatorname{TFM}\left({ }^{\circ} \mathrm{C}\right)$ & $\begin{array}{l}\text { Number of fluid } \\
\text { inclusion }\end{array}$ & Number of sample \\
\hline $\mathrm{P}$ & - & $\mathrm{L}+\mathrm{V} \rightarrow \mathrm{L}$ & 322 & - & - & 4 & 5 \\
\hline $\mathrm{P}$ & - & $\mathrm{L}+\mathrm{V} \rightarrow \mathrm{L}$ & 313 & - & - & 2 & 5 \\
\hline $\mathrm{P}$ & 11.7 & $\mathrm{~L}+\mathrm{V} \rightarrow \mathrm{L}$ & 310 & -8 & - & 1 & 1 \\
\hline $\mathrm{P}$ & 12.05 & $\mathrm{~L}+\mathrm{V} \rightarrow \mathrm{L}$ & 309 & -8.3 & -48 & 1 & 1 \\
\hline $\mathrm{P}$ & 11.82 & $\mathrm{~L}+\mathrm{V} \rightarrow \mathrm{L}$ & 307 & -8.1 & _ & 1 & 1 \\
\hline $\mathrm{P}$ & - & $\mathrm{L}+\mathrm{V} \rightarrow \mathrm{L}$ & 295 & - & - & 1 & 5 \\
\hline $\mathrm{P}$ & 22.5 & $\mathrm{~L}+\mathrm{V} \rightarrow \mathrm{L}$ & 292 & -25 & -69 & 1 & 1 \\
\hline $\mathrm{P}$ & 22.7 & $\mathrm{~L}+\mathrm{V} \rightarrow \mathrm{L}$ & 288 & -25.5 & - & 1 & 1 \\
\hline $\mathrm{P}$ & 23.5 & $\mathrm{~L}+\mathrm{V} \rightarrow \mathrm{L}$ & 285 & -26.6 & -68.2 & 2 & 1 \\
\hline $\mathrm{P}$ & 22 & $\mathrm{~L}+\mathrm{V} \rightarrow \mathrm{L}$ & 278 & -24.5 & -67 & 1 & 1 \\
\hline $\mathrm{P}$ & 23.1 & $\mathrm{~L}+\mathrm{V} \rightarrow \mathrm{L}$ & 274 & -26 & -57 & 1 & 1 \\
\hline $\mathrm{P}$ & 23.4 & $\mathrm{~L}+\mathrm{V} \rightarrow \mathrm{L}$ & 253.5 & -26.5 & -54 & 3 & 2 \\
\hline $\mathrm{P}$ & 22.87 & $\mathrm{~L}+\mathrm{V} \rightarrow \mathrm{L}$ & 251 & -25.4 & -54 & 2 & 2 \\
\hline $\mathrm{P}$ & 23.1 & $\mathrm{~L}+\mathrm{V} \rightarrow \mathrm{L}$ & 249 & -26 & -54 & 1 & 2 \\
\hline $\mathrm{P}$ & 23.29 & $\mathrm{~L}+\mathrm{V} \rightarrow \mathrm{L}$ & 248 & -26.3 & -53 & 1 & 2 \\
\hline $\mathrm{P}$ & 23.19 & $\mathrm{~L}+\mathrm{V} \rightarrow \mathrm{L}$ & 227 & -26.2 & -57 & 1 & 2 \\
\hline $\mathrm{P}$ & - & $\mathrm{L}+\mathrm{V} \rightarrow \mathrm{L}$ & 213 & - & - & 1 & 5 \\
\hline $\mathrm{P}$ & 17.68 & $\mathrm{~L}+\mathrm{V} \rightarrow \mathrm{L}$ & 205 & -18.2 & - & 1 & 5 \\
\hline $\mathrm{P}$ & 20.7 & $\mathrm{~L}+\mathrm{V} \rightarrow \mathrm{L}$ & 196 & -22.7 & - & 1 & 7 \\
\hline $\mathrm{P}$ & 20.8 & $\mathrm{~L}+\mathrm{V} \rightarrow \mathrm{L}$ & 193 & -22.8 & - & 2 & 7 \\
\hline $\mathrm{P}$ & 21.12 & $\mathrm{~L}+\mathrm{V} \rightarrow \mathrm{L}$ & 187 & -23.1 & - & 2 & 7 \\
\hline $\mathrm{P}$ & 21.2 & $\mathrm{~L}+\mathrm{V} \rightarrow \mathrm{L}$ & 186 & -23.2 & - & 1 & 7 \\
\hline $\mathrm{P}$ & 17.8 & $\mathrm{~L}+\mathrm{V} \rightarrow \mathrm{L}$ & 177 & -18.5 & - & 2 & 5 \\
\hline
\end{tabular}

MS method and 8 samples of them were analyzed by XRF method in Zar Azma laboratory in Iran. Results of this analysis are listed in Table 1.

\subsection{Classification of Volcanic Rocks}

The compositions of igneous rocks from the Aftabrou volcanic rocks are plotted on the total alkali-silica diagram, TAS (Cox et al., 1979). Basaltic andesites and trachy-andesites are rare in the Aftabrou, occurring in significant numbers only at east of area (Figure 5(a)).

\subsection{Nature of Former Magma of Volcanic Rocks}

As is ploted in Figure 5(a), nature of this magma is subalkaline and calcalkaline (Figure 5(b)).

\section{Petrography of Mineralization in Aftabrou Area}

In order to recognization of metal ore, petrography of mineralization in rock 

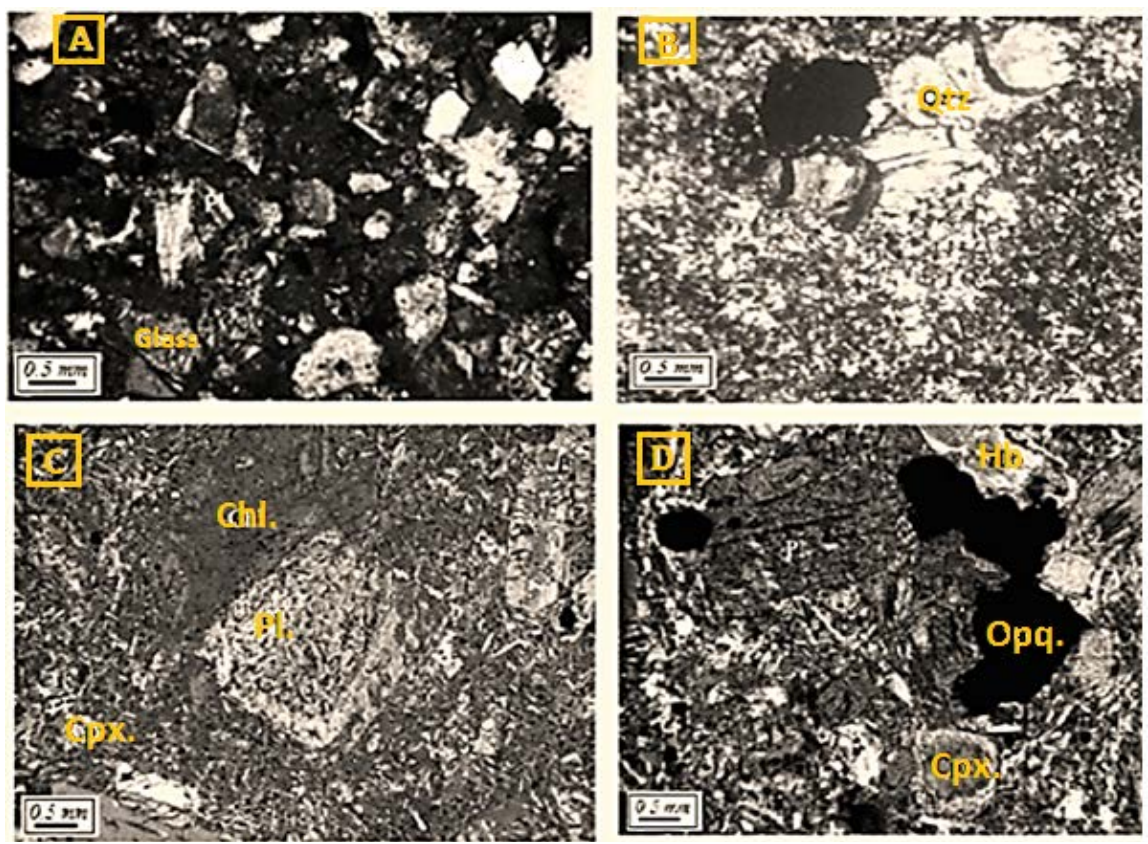

Figure 4. Photomicrographs of volcanic rocks from the Aftabrou Area. (A) Tuff crystal vitric with prominent quartz, volcanic glass and plagioclase and destructal texture, (B) Dacitic tuff with phenocryst of quartz, alkalifeldespar, biotite and opac and sericite porphyritic with glassy and fine grain microgranular mesostasis texture, (C) Andesite with plagioclase and hornblende and porphyromicrolitic texture, (D) Andesite with phenocryst of plagioclase, hornblende, clinopyroxen and opac minerals and porphyric texture with microgranular mesostasis.

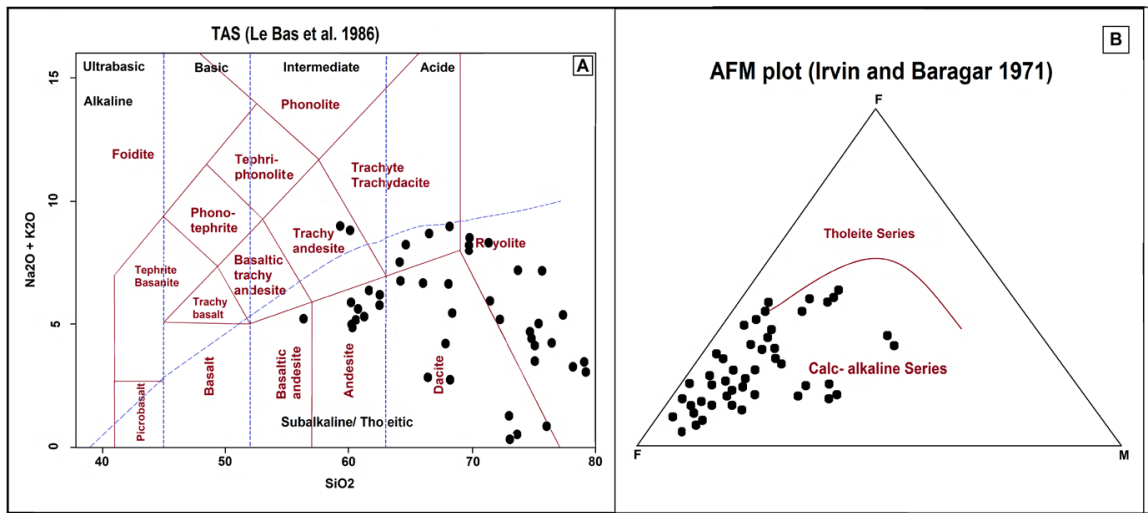

Figure 5. (A) The status of volcanic samples in the graphs of TAS (Cox et al. 1979) and (B) in AFM graph, for separation calc-alkaline and tholeiitic series.

samples is studied. To petrographic studies of mineralization in Aftabrou area, 60 unsystematic lithogeochemical samples that were altered and mineralized from breccia and silicified zone in contact of volcanic and plutonic-sub plutonic rocks and toward volcanic, plutonic-sub plutonic, are selected. This study is done with preparation polish and thin section.

In macroscopic study which rocks are in light gray-gray to light brown-brown color with fractures and vents that filled by iron hydroxides and carbonates (Figure 6(a), Figure 6(b)). High hardness and its appearance defined it "silisic 

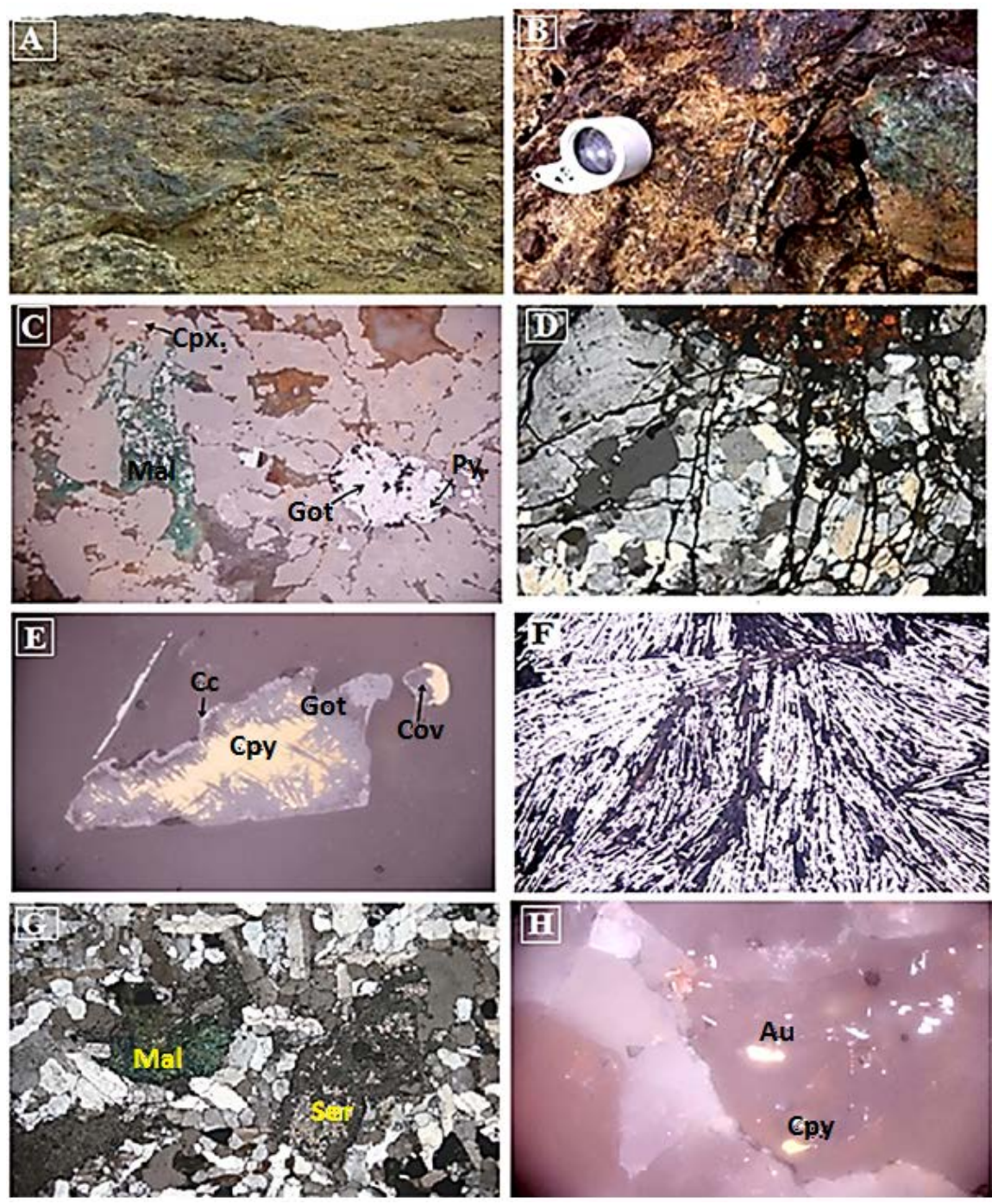

Figure 6. (A) Background of silicified and brecciated zone that shown evidences of surface $\mathrm{Cu}$ mineralization, (B) In the form of malachite chalcopyrite and pyrite. (C) Malachite between unhedral crystals of quartz pyrite convert to goethite single grain of chalcopyrite in polish section ( $\times 40$ magnification in PPL light). (D) Thin section of silisic rocks that shown two generations of quartz and pull-aparts $(\times 5$ magnification in XPL light). (E) Yellow brass chalcopyrite, gray to light blue chalcocite, orange bornite, indigo covelite and goethite ( $\times 40$ magnification in PPL light). (F) Mixed blades of specularite $(\times 40$ magnification in PPL light). $(G)$ Plagioclase convert to sericite, completely $(\times 5$ magnification in XPL light). $(\mathrm{H})$ Very bright grain Suspected gold $(\times 40$ magnification in PPL light).

rock". This rocks in microscopic study, thin section, contain of auhedral to unhedral crystal of silica in different sizes from very fine grain to coarse grain (Figure 6(d)). There are many fractures that filled with opac mineral (Figure $6(d))$. There are double generations of silica in this sample, that delay silica in comparision to once generation, have more coarse-grained. Primary texture in all of them is disappeared.

Polish section is shown a lot of auhedral to unhedral crystals of pyrite and deposit of malachite adminst them and many fine grain of single crystal of chal- 
copyrite (Figure 6(c)). Pyrites, more time, completely, sometimes, slightly, convert to goethite (Figure $6(\mathrm{c})$ ). In most of thin and polish sections extension joints in to pull-apart, are seen, that most filled with metal minerals.

\section{Geochemistry of Mineralization in Aftabrou Area}

In order to apply geochemical mineralization study, 22 unsystematic lithogeochemical samples were analyzed. Results of this analyze is shown in Table 2. Location of this sampling point is shown in Figure 7. According to data from Table 2, three main anomalies are found in this area.

\subsection{Copper Mineralization}

According to data from Table 2, Cu element has $0.2 \%-5.3 \%$ tenor and locating this on the satellite photo, highlighting $\mathrm{Cu}$ mineralization zone as shown in Figure 8. This zone have $1.2 \mathrm{Km}$ length and $150 \mathrm{~m}$ width and surface oxide mineralization in to vein and veinlet (mainly malakite) and sulfidic (mainly chalcopyrite), is located in south eastern of Aftabrou pluton (Figure 8). Field photo of this zone and close up of its mineralization texture is shown in Figure 9.

\subsection{Gold Mineralization}

According to data from Table 2 gold concentration varies from 0.02 to 1.31 ppm (Figure 10) that is occur in andesitic/granodoritic and tuffic rocks, depts from 6 - 28 meters, that in $18-20 \mathrm{~m}$ in tuffic rocks is maximum and in $6-8 \mathrm{~m}$ in andesitic-granodioritic rocks is minimum. This zone has $400 \mathrm{~m}$ length and 70 $\mathrm{m}$ width, is located in western of Aftabrou pluton (Figure 10). Textuer of this mineralization is breccial and stockwork (Figure 11(C), Figure 11(D)).

\subsection{Zinc Mineralization}

According to data from Table 2, Zinc concentration varies from $1.2 \%$ to $3.9 \%$

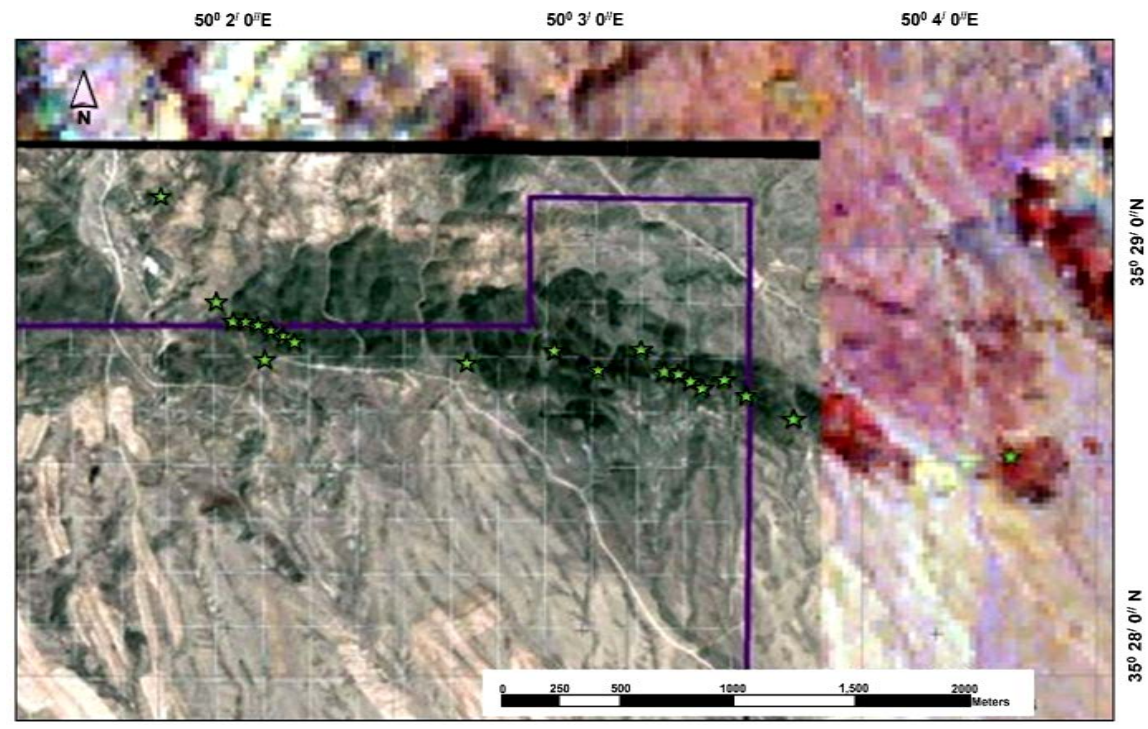

Figure 7. Sample location at the Aftabrou area. 


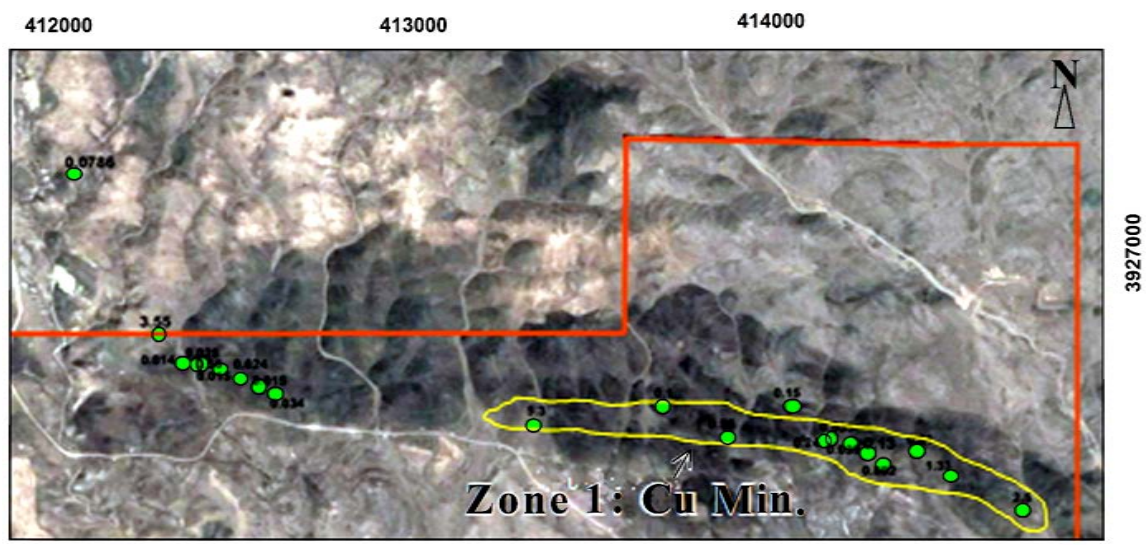

$\mathrm{Cu}-\%$

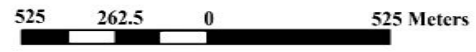

Figure 8. Copper mineralization zones Aftabrou area.

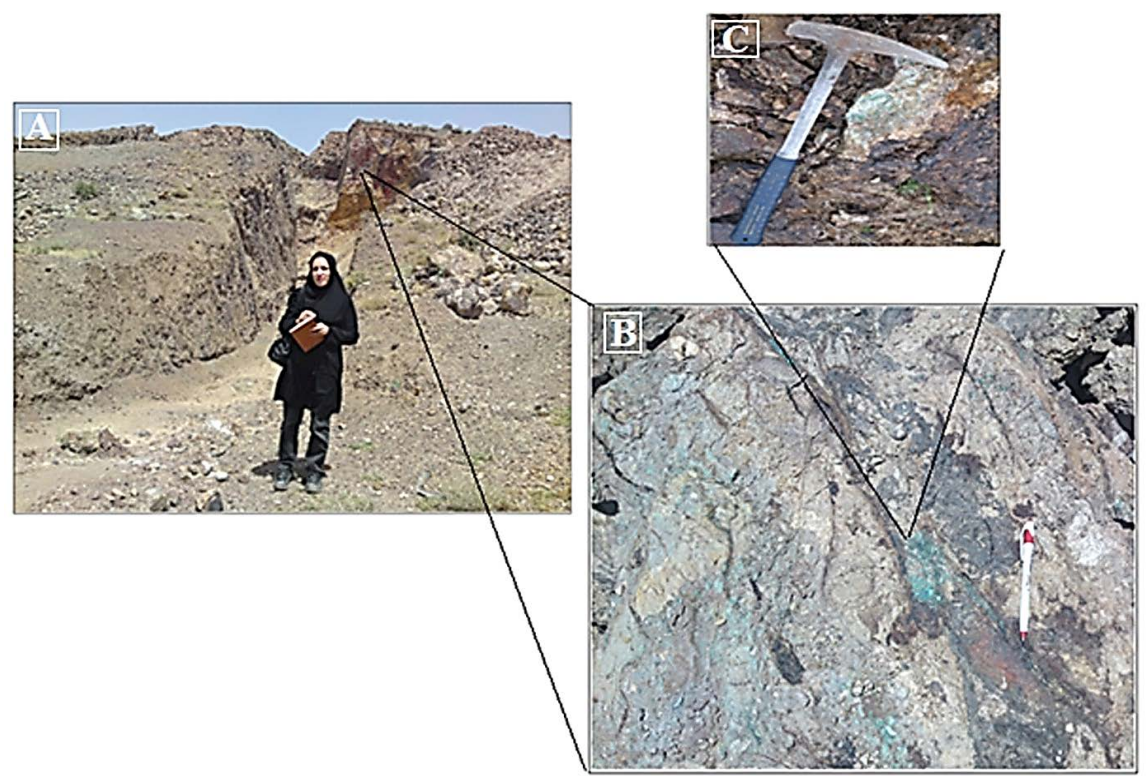

Figure 9. (A) Copper mineralization zone in southeastern part of the Aftabrou deposit; (B) Close up of this mineralization; (c) Texture of $\mathrm{Cu}$ mineralization.

(Figure 12). In this zone tenor of $\mathrm{Cu}$ is $0.5 \%$ and in form of several streak, have $70 \mathrm{~m}$ length and $2-5 \mathrm{~m}$ width (Figure 12, Figure 13). This mineralization occurs in black color andesite-basaltic unit.

\section{Fluid Inclusion Study of the Aftabrou}

A total of 7 samples were collected from the different Levels of deposit as well as outcrop samples from the quartz veins related to mineralization (Figure 14), out of which fresher and unweathered samples were selected for fluid inclusion petrography and its micro thermometry. The advantages of using of quartz, are lack of cleavage and ability easy recrystallization that do it appropriate environment for protection of fluid inclusions [12]. Petrographic studies of the polished section and doubly polished thin sections $(\sim 100 \mu \mathrm{m}$ thick) of quartz were carried 


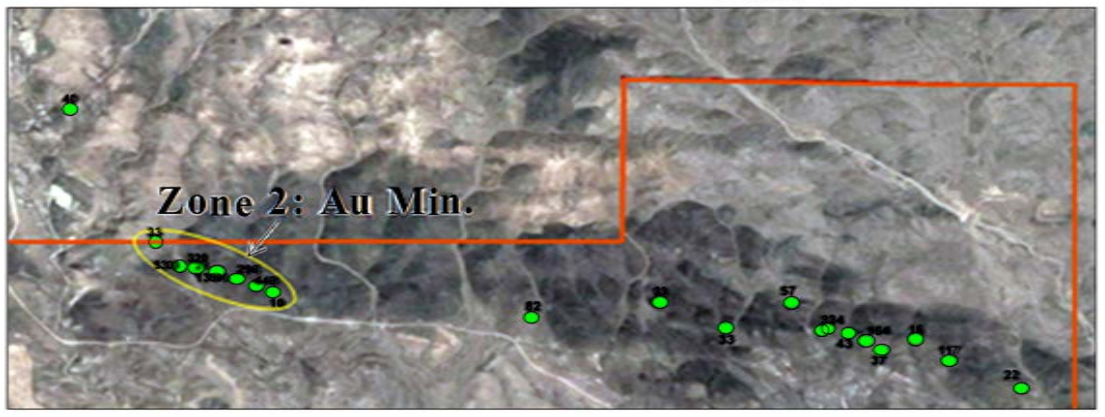

Au- ppb
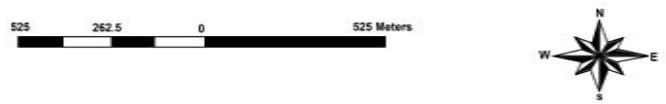

Figure 10. Gold mineralizaed zones at Aftabrou area.
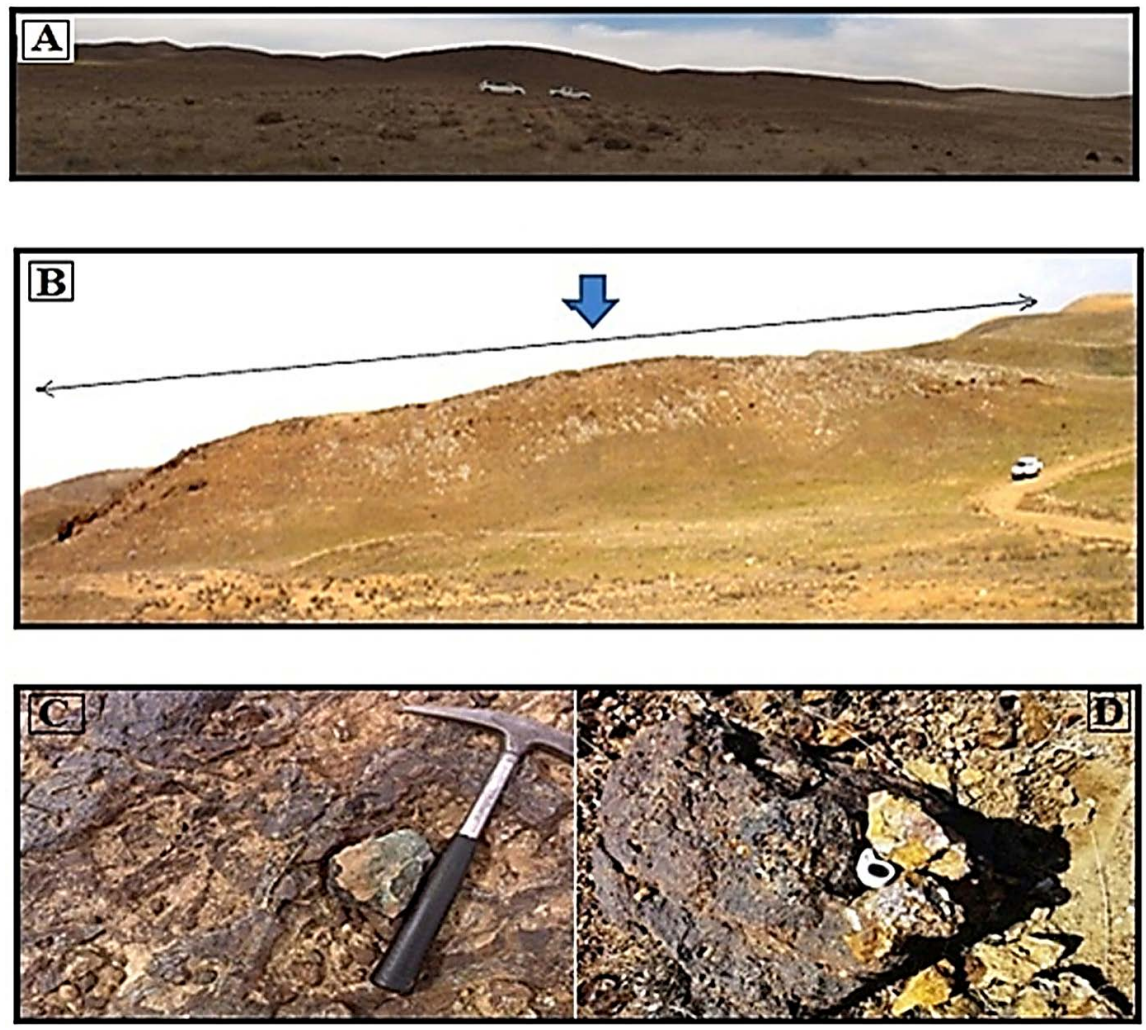

Figure 11. (A, B) Gold mineralization zone in western part of the Aftabrou deposit, (C) Close up of stockwork mineralization zone containing gold with tenor of $1.31 \mathrm{ppm}$ and (D) silicified and breccial zone containing Au mineralization.

out under transmitted and reflected light respectively. The measurements were performed on a Linkam THMS 600 combined heating/freezing stage at the Isfahan University. This device can measure temperatures ranging from $-200^{\circ} \mathrm{C}$ to $+600^{\circ} \mathrm{C}$. The main purpose of micro thermometric study was to observe and record the different phase transitions within the fluid inclusions in response to temperature changes. Studied fluid inclusions are mostly primary, Para genetically, that are formed in early stage of mineral growth. Secondary fluid is rarely and stays on unit along (along fracture planes of quartz). Primary fluid inclusions 


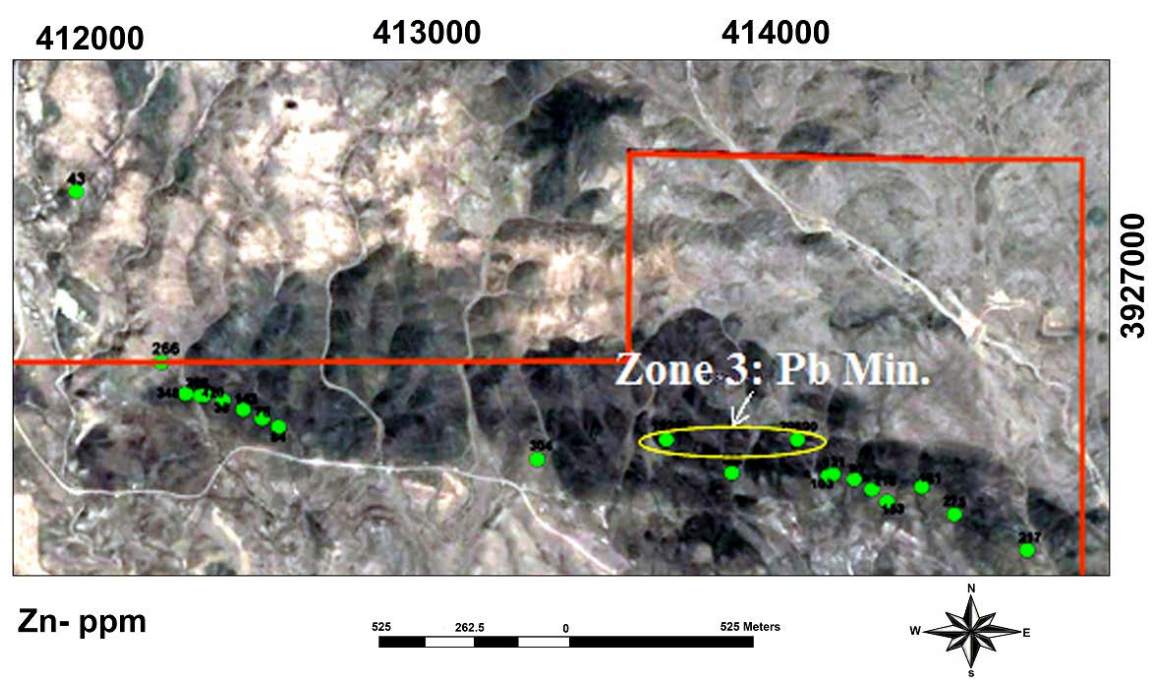

Figure 12. Zinc mineralized zones in Aftabru area

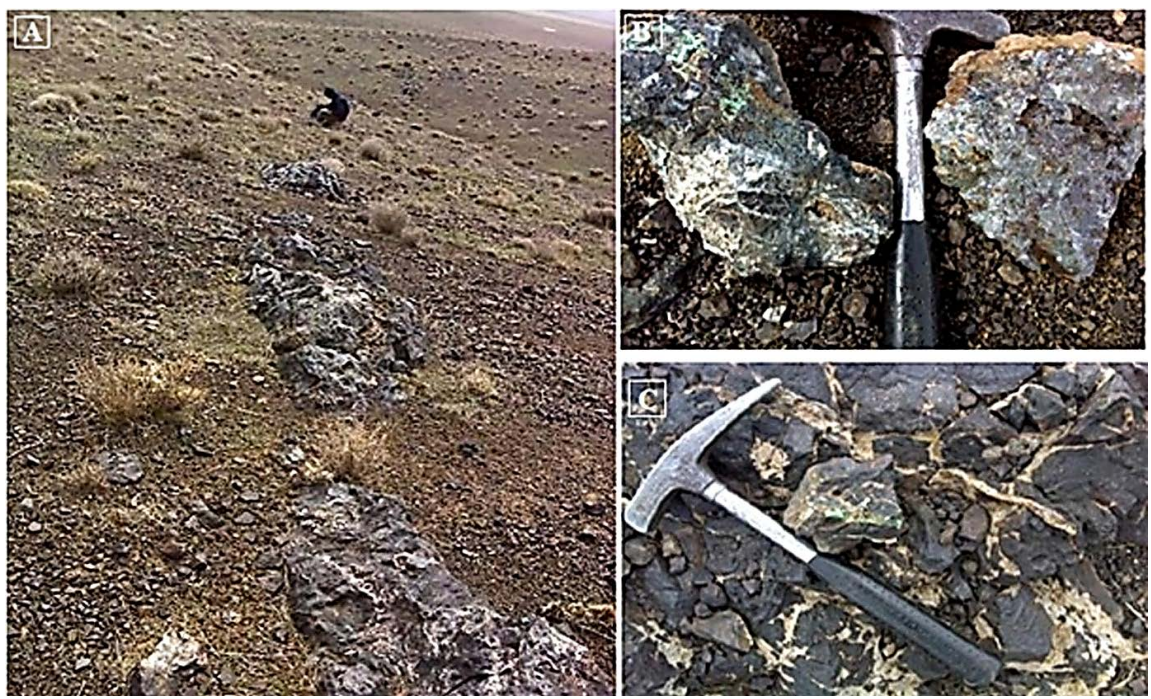

Figure 13. (A) Zn mineralization zone in Aftabrou area; (B) Close up of silicified streaks containing $\mathrm{Zn}$ oxide mineralization with a few copper oxides; (C) Silicified streaks containing chalcopyrite and malachite in $\mathrm{Zn}$ zone.

of quartz are more stylish, full and coarse than secondary, in microscopic studies. This study proved that they are the best method for determinate of temperature of deposit. They are in lens and erratic form. Lack of special form in this suggests that entrapment of fluids is due to lack of special form in spaces of crystal surfaces. Size of cavities is 3 - 25 micron and most frequency related to cavities from 10 - 15 micron and containing of fluid (two-phase liquid bearing). Most degree of rich is $80 \%$. Any fluid inclusion containing $\mathrm{CO}_{2}$ or solid phase is seen. All of these stages investigate, optically, then stages of freezing and heating was formed on inclusions. The stage was calibrated using a set of synthetic fluid inclusion standards from Syn Flinc, with a precision of $\pm 0.1^{\circ} \mathrm{C}$ at sub ambient conditions and $\pm 1^{\circ} \mathrm{C}$ at higher temperatures. Salinities of liquid-rich fluid inclusions were calculated from measured ice-melting temperatures using the 


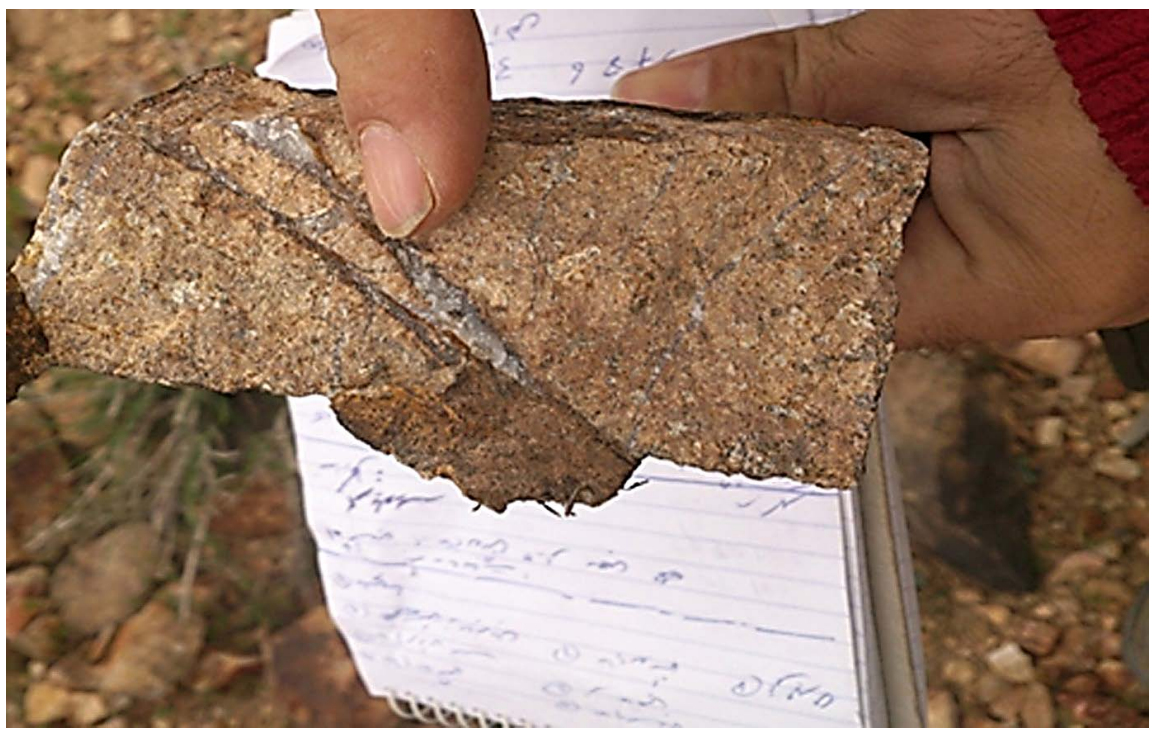

Figure 14. Veinlet example of quartz was selected for fluid inclusion studies.

equation [13]. Whereas the equation of [14] was used to calculate salinity from halite-melting temperatures.

\section{Micro Thermometric Studies}

The aim of investigations of fluid inclusion thermometry in heating stage, is getting homogenization temperature of different phases of fluid inclusion that is result of temperature of fluid with the temperature of mineral formation. Results of investigation of micro thermometry on fluid inclusion of polymetallic deposit of Aftabrou are in Table 3. As it seen two phase of this fluid, liquid and vapor, is present in this system, without solid phase.

Determination of homogenization temperature: Studies is shown two major phase of inclusion, watery solution and a moving bubble of vapor. During thermometry, related to frequency feather of phases, homogenization can do related to dominant phase. For inclusion fluid contained net water, real form of homogenization is determined by overall density. Although this is more complex for fluid containing more diverse, thus, two types of inclusions are seen in this study:

a. Liquid, is form major part of fluid ( $>50 \%)$ and bubble of vapor was not impressive, homogenized to liquid, during homogenization. Temperature of this group is $200^{\circ} \mathrm{C}-300^{\circ} \mathrm{C}$ and more of them are in this group (Figure 15(a)).

b. Bubble of vapor is larger and less volume of liquid is form this $(<25 \%)$. Samples of this is small and not studied (Figure 15(b)).

Histogram of homogenization temperature of fluid inclusion (Figure 16) is shown that formation of available mineral in hydrothermal veins is occurred in more one stage of mineralization, but in medium and low temperature.

Freezing method: Freezing studies is used for salinity determination in waterrich fluid. In this case, the measurement of temperature of ice final melting 
(a)

(b)

Figure 15. (a) Fluid inclusion liquid-rich (15 micron); (b) Fluid inclusion vapor-rich (12 micron).

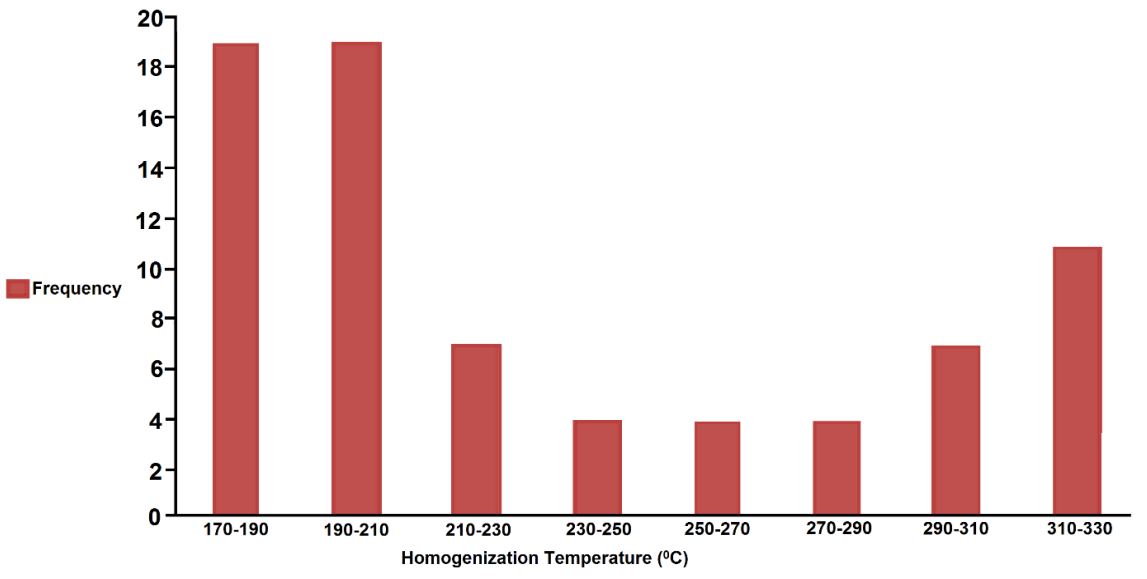

Figure 16. Histogram of homogenization temperatures of fluid inclusion in Aftabrou deposit

during the reheating on fluid inclusion will helpful [15]. In due to difficulty to determination of type of saline in fluid inclusion, reported melting temperature of ice in to percentage of weight. Melting temperature of 19 fluid inclusions is determined. Then in order to determination of salinity in fluid inclusions (that are two phase, vapor and liquid) is used following equation that used for systems without solid crystals of salt [16]:

$$
\text { Salinity }(W t 0 / 0)=1.76958-4.2384 * 10202+5.3 * 10-403+0.28
$$

$\mathrm{Tfm}$ is measured for 10 samples and is from $-48^{\circ} \mathrm{C}$ to $-69^{\circ} \mathrm{C}$. In this study final melting temperatures of ice (Tlm) is changed from $-8^{\circ} \mathrm{C}$ to $-26.6^{\circ} \mathrm{C}$. This volume is shown range of salinity from $11.7 \%$ to $23.7 \% \mathrm{wt} \mathrm{NaCl}$ and medium salinity, 20. 24\%wt. Lack of daughter phase may be in due to medium salinity [17] and mixing with atmospheric water [16]. 
Depth of fluid inclusion entrapment is determined less than $1800 \mathrm{~m}$ of surface, by using the temperature of homogenization and pressure curve in diagram from (Figure 17).

Density of mineralization fluid is determined from $0.8-1.1 \mathrm{gr} / \mathrm{cm}^{3}$, by using the percentage weight of salinity vs. temperature homogenization in diagram from [15] (Figure 18).

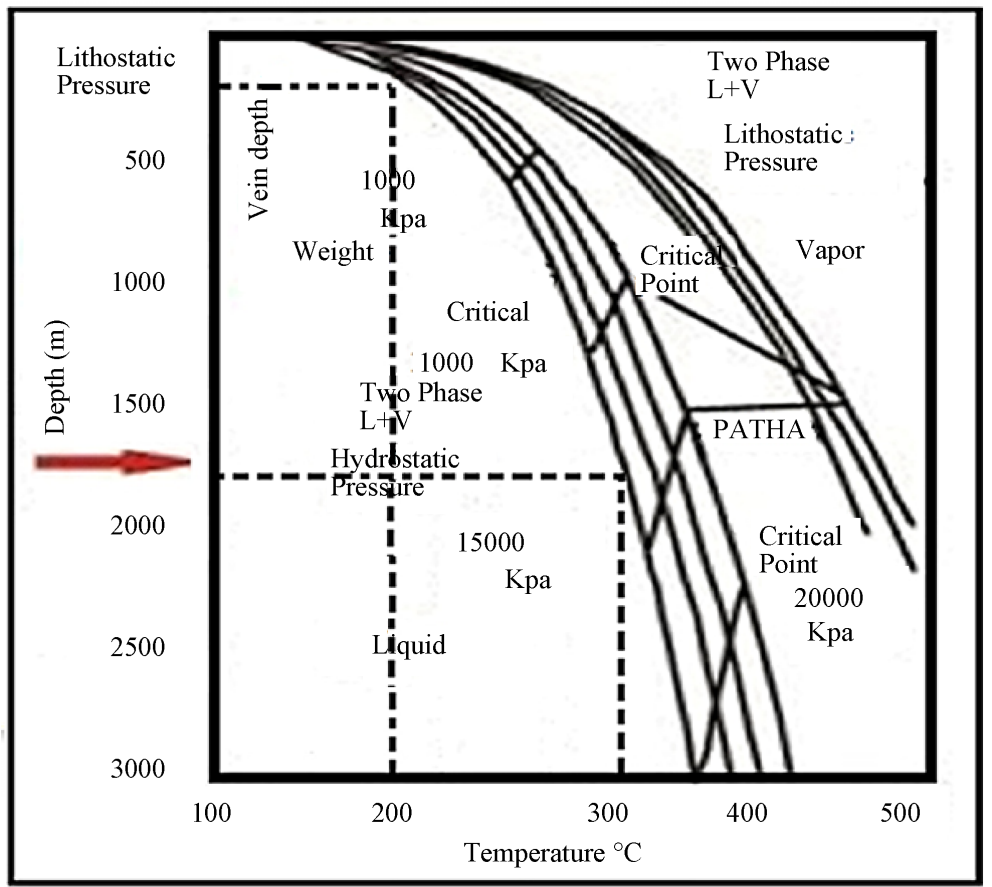

Figure 17. Determination diagram for depth on the basis of homogenization temperature.

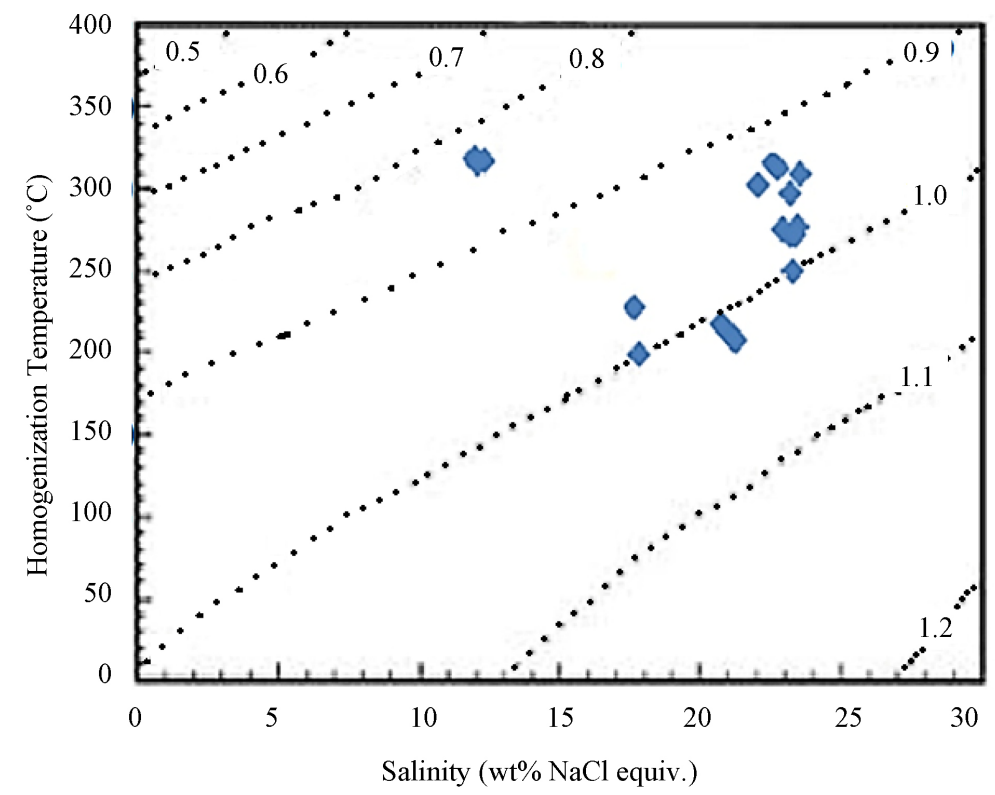

Figure 18. Determination diagram for density on the basis of salinity vs. homogenization temperature. 
Vapor pressure of fluid is determined less than 100 atmosphere, by using the percentage weight of salinity vs. temperature homogenization in diagram from (Figure 19).

Determination of deposition formation and type of mineralization in Aftabrou deposit: Formation of mineral deposit is simple on the basis of obtained data. In the other words, decrease of fluid temperature is from fractures up to surface with atmospheric water mixing. According to presence of small vapor and medium salinity phases in samples, can point to fluid mixing. But, according to lack of $\mathrm{CO}_{2}$ in samples and coexistence of vapor and liquid-rich fluid, cannot exact boiling occurrence [18]. So, trend of samples in diagram [15], deposit mechanism of mineral in veins, is simple cooling and mixing with atmospheric water (Figure 20).

Aftabrou is in below range of deposit IOCG (from Cu-Au-Bi-Fe Oxide Type), on the basis of salinity- homogenization temperature diagram [15] (Figure 21).

\section{Conclusion}

Rocks in Aftabrou area were 3 groups of volcanic, plutonic and sub plutonic. Plutonic rocks are granodiorite to diorite [7] [11]. Sub plutonic rocks, only, are

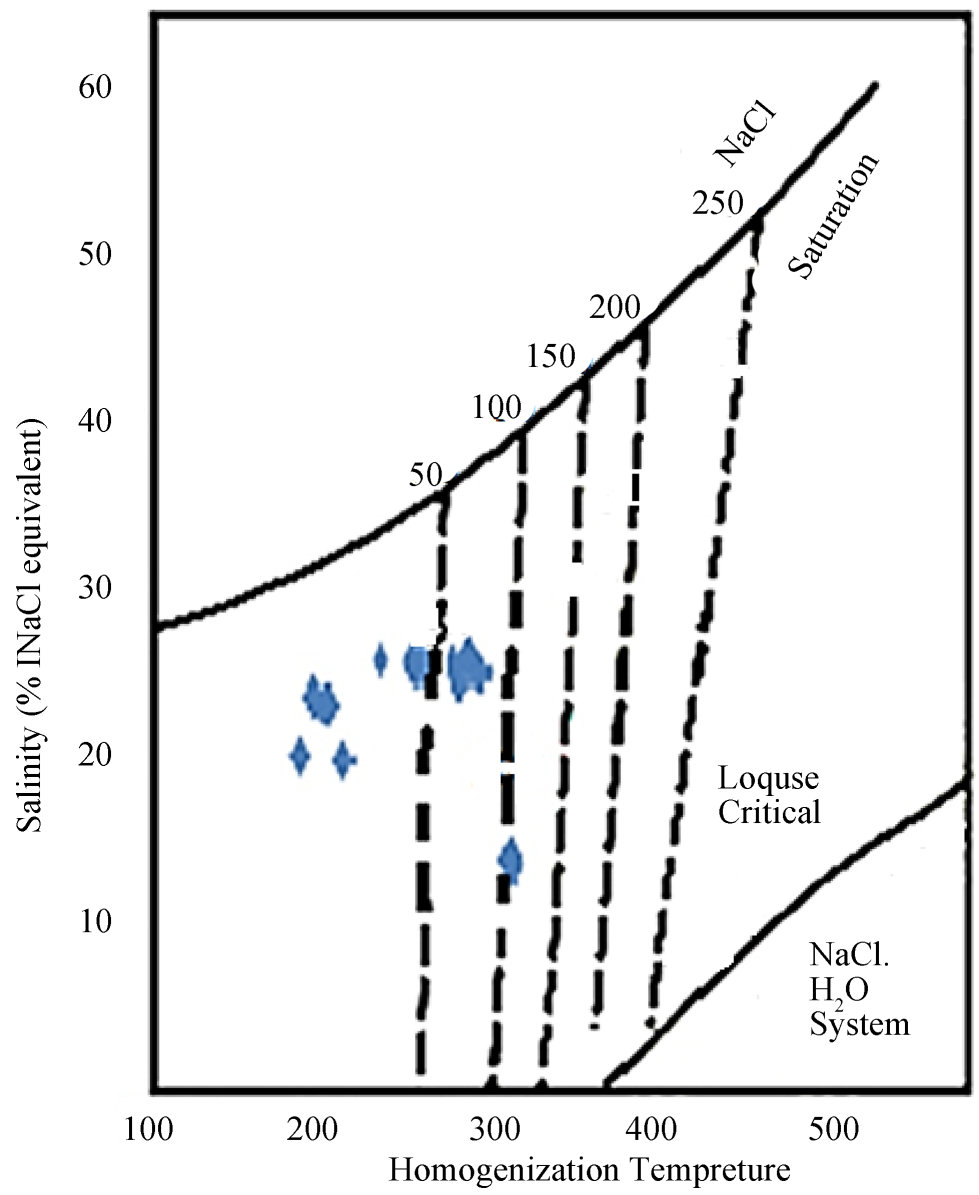

Figure 19. Determination diagram for vapor pressure of fluid on the basis of salinity vs. homogenization temperature. 

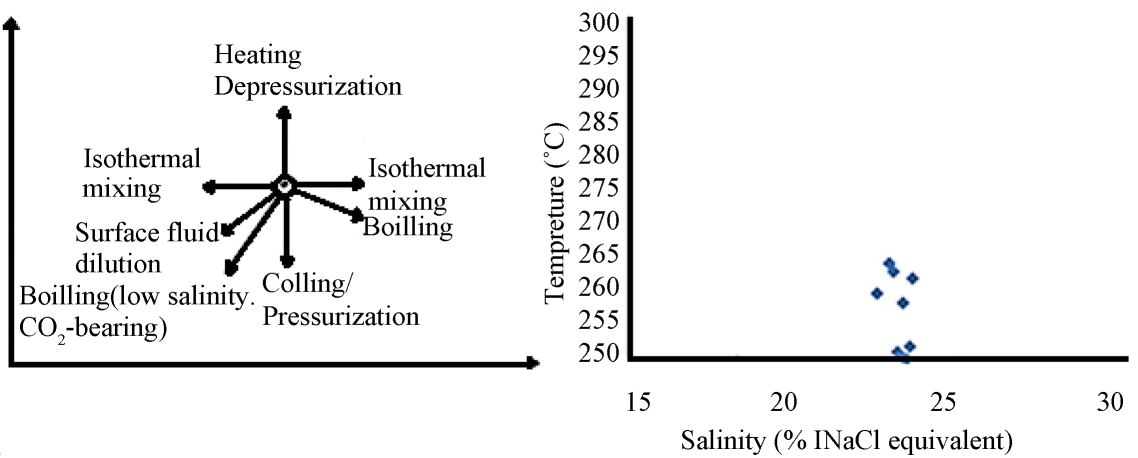

Figure 20. Salinity-Homogenization temperature for determination of deposit mechanism [15].

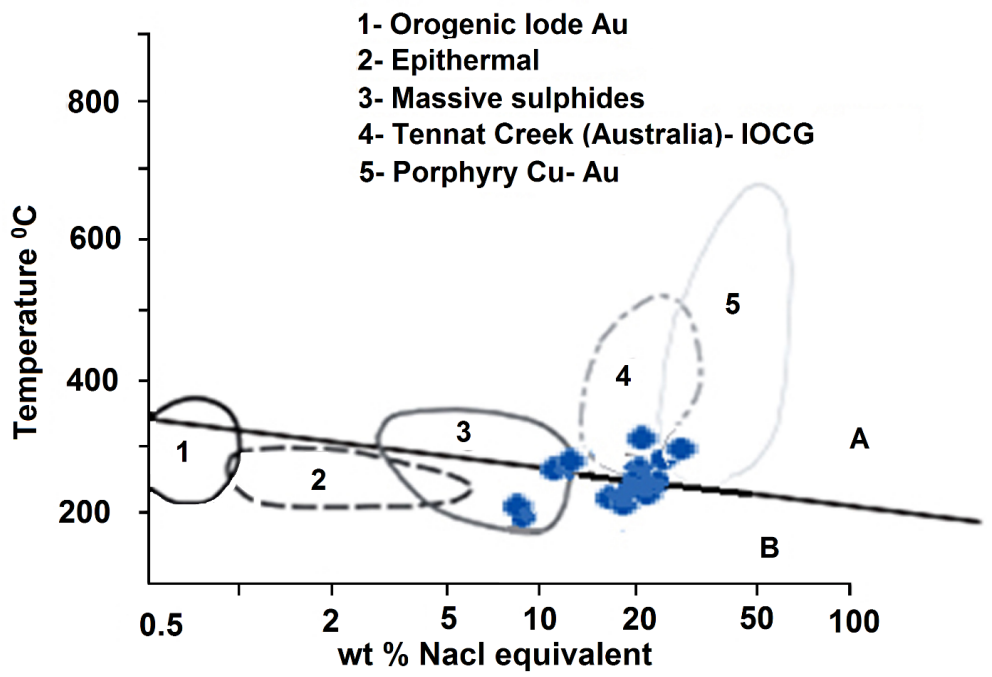

Figure 21. Homogenization temperature vs. salinity for determination the type of deposit

included diorite [7]. Geochemical studies shown that calc-alkaline, I-type magma formed plutonic rocks, alkaline magma formed sub plutonic rocks in Aftabrou area [11] and subalkaline-calcalkaline I-type magma formed volcanic rocks. Volcanics involved of andesitic to dacitic tuff and lava that show porphyritic texture with glassy and fine grain microgranular to microgranular mesostasis. The mineral is distinct and specified values of phenocrysts of quartz, alkalifeldespar, biotite, plagioclase, hornblende, clinopyroxen and opac minerals.

Copper mineralization with $0.2 \%-5.3 \%$ tenor are related to vein and veinlet (mainly malakite) and sulfidic (mainly chalcopyrite), in south eastern of Aftabrou pluton. Breccial and stockwork Gold mineralization with 0.02 to $1.31 \mathrm{ppm}$ is occured in andesitic/granodoritic and tuffic rocks. Zinc mineralization with $1.2 \%$ to $3.9 \%$ occurs in black color andesite-basaltic unit. Field observations, petrographic and geochemical studies are shown that mineralization is more related to vein and veinlet of quartz.

Fluid inclusion studies of quartz two type of inclusion are shown, liquid, that is form major part $(>50 \%)$ and vapor that is small and not studied $(<25 \%)$. 
Temperature of homogenization of this fluid is shown that available mineral occurd in more one stage of mineralization, but in medium and low temperature. By freezing method range of salinity from $11.7 \%$ to $23.7 \% \mathrm{wt}$, medium salinity, with density from $0.8-1.1 \mathrm{gr} / \mathrm{cm}^{3}$ and vapor pressure less than 100 atmosphere in depth less than $1800 \mathrm{~m}$ of surface are formed. Lack of daughter phase may be in due to medium salinity [17] and mixing with atmospheric water [16].

According to this information, formation of mineral deposit is simple. In the other words, decrease of fluid temperature is from fractures up to surface with atmospheric water mixing. According to presence of small vapor and medium salinity phases in samples, can point to fluid mixing. But, according to lack of $\mathrm{CO}_{2}$ in samples and coexistence of vapor and liquid-rich fluid, cannot exact boiling occurrence [18]. So, trend of samples in diagram [15], deposit mechanism of mineral in veins, is simple cooling and mixing with atmospheric water [19].

Most IOCG deposits have mineral assemblages that imply the ore fluids were oxidized and sulfide poor, although host rocks locally appear to have influenced the formation of more reduced [19]. Fluid inclusions indicate that the ore fluids were saline and the overall impression is that these deposits formed from fluids with high $\mathrm{Cl} / \mathrm{S}$ [20]. The geologic evidence presents a complex picture with key features including the following:

IOCG deposits are associated with igneous rocks that range from diorites to granites [21]. Mineralization and associated alteration occurred at submagmatic temperatures [21]. There is generally strong, but not universal, evidence for coeval magmatism with different regions having different compositional intrusive suites [21]. For example, in Mantoverde system of Chilean IOCG deposits, as seen as, Aftabrou mineralization occured related to volcanic, volcanoclastic and locally intrusive host rocks from calcalkaline I-Type magmatism in volcanic arc setting with concentrations of $\mathrm{Zn} \mathrm{[22]} \mathrm{and} \mathrm{they} \mathrm{are} \mathrm{typically} \mathrm{polymetallic,}$ with one or more economic metals that may include various combinations of $\mathrm{Fe}$, $\mathrm{Cu}, \mathrm{Au}, \mathrm{Ag}, \mathrm{U}, \mathrm{Th}, \mathrm{F}, \mathrm{Co}, \mathrm{Bi}, \mathrm{W}$, rare earth elements (REE) and other metals. Properties such as mineralization are associated with intermediate Cenozoic intrusive and semi intrusive [23], view of alteration and mineralization in a wide range [21]. Epigenetic mineralization, as seen as Aftabrou, in many other parts of the world such as Mantoverde IOCG system of Chilean [22], IOCG deposits in Canada [24], world's Mesozoic arc northern Chile and southern Peru [25], Iron Oxide Copper-Gold deposits (IOCG) are reported in frontier felsic to intermediate volcano-plutonic terrains [24]. On the other, Aftabrou is in below range of deposit IOCG (from $\mathrm{Cu}-\mathrm{Au}-\mathrm{Bi}-\mathrm{Fe}$ Oxide Type), on the basis of salinityhomogenization temperature diagram [26].

On the other, in term of geodynamic setting, Aftabrou intrusion is classified as volcanic arc (VAG) and active continental margin (CAG) which have been formed as a result of Neotethys oceanic crust subduction beneath the Central Iran continental crust [7]. 
According to this, it is assumed that Aftabrou IOCG deposit is occurred associate with magmatism that is formed as a result of Neotethys oceanic subduction beneath the Central Iran zone which is replaced in the Orumieh-Dokhtar magmatic arc.

According to conducted research, genetic model(s), origin of fluids and processes of metal recharge and discharge during the alteration, brecciation and ore deposition processes that lead to IOCG(U) deposits remain poorly understood [24]. On the other, knowledge gaps can be partially attributed to the recent recognition of this deposit-type and the importance of pre-enrichment of their hosts to generate uranium-rich deposits. The nonsystematic geometry and the diversity of known deposits, the complexity of possible ore-forming processes, and the non-exposed nature of many IOCG(U) deposits (e.g., Olympic Dam) [24], are other than the need for further study of these reserves. Stable isotopes will be required in order to determine the accurate understanding of the origin of mineralizing fluid. IOCG deposits are currently viewed as the most challenging field of research in contemporary economic geology [21], it is suggested this deposit will be undergoing extensive exploration.

\section{References}

[1] Afshooni, S.Z., Mirnejad, H., Esmaeily, D. and Asadi, H.H. (2013) Mineral Chemistry of Hydrothermal Biotite from the Kahang Porphyry Copper Deposit (NE Isfahan). Central Province of Iran. Ore Geology Reviews, 54, 214-233.

[2] Ayati, F., Yavuz, F., Asadi, H.H., Richards, J.P. and Jourdan, F. (2013) Petrology and Geochemistry of Calc-Alkaline Volcanic and Subvolcanic Rocks, Dalli Porphyry Copper-Gold Deposit, Markazi Province, Iran. International Geology Review, 55, 158-184. https://doi.org/10.1080/00206814.2012.689640

[3] Azadi, M., Mirmohammadi, M. and Hezarkhani, A. (2014) Aspects of MagmaticHydrothermal Evolution of Kahang Porphyry Copper Deposit, Central Iran. Arabian Journal of Geosciences, 8, 4873-4893. https://doi.org/10.1007/s12517-014-1528-2

[4] Asadi, H.H., Porwal, A., Fatehi, M., Kianpourian, S. and Lu, Y.J. (2015) Exploration Feature Selection Applied to Hybrid Data Integration Modeling: Targeting Copper-Gold Potential in Central Iran. Ore Geology Reviews, 71, 819-838.

[5] Amini-Haroni, I. (2014) Mineralogy and Geochemistry of the Aftabru Poly Metal Prospect, Markazi Province. MSc Thesis, Geology Department, Isfahan University, Isfahan, 127 p. (In Persian)

[6] Asadi, H.H., Kianpouryan, S., Lu, Y.J. and McCuaig, T.C. (2014) Exploratory Data Analysis and C-A Fractal Model Applied in Mapping Multi-Element Soil Anomalies for Drilling: A Case Study from Sari Gunay Epithermal Gold Deposit, NW Iran. Journal of Geochemical Exploration, 145, 233-241.

[7] Sabzian, A., Masoudi, F., Emami, M.H. and Nezafati, N. (2015) The Study of Dual Entity of Alkaline-Calcalkaline Magma Origin in Plutonic Rocks in Aftabrou Area, North West of Saveh, Arak. Journal of Biodiversity and Environmental Science, 6 , 428-437.

[8] Emami, M.H. (2000) Magmatism in Iran. Published by the Geological Survey and Mineral Exploration Iran. 
[9] Soltani, V. and Asadi, H.H. (2013) Preliminary Exploration Report of Aftabru IOCG Prospect. Open File Report, Dorsa Pardazeh Company, Markazi Province, 73.

[10] Hezarkhani, A. and Williams-Jones, A.E. (1998) Controls of Alteration and Mineralization in the Sungun Porphyry Copper Deposit, Iran: Evidence from Fluid Inclusions and Stable Isotopes. Economic Geology, 93, 651-670.

https://doi.org/10.2113/gsecongeo.93.5.651

[11] Sabzian, A., Masoudi, F., Asadi Harooni, H., Emami, M.H. and Nezafati, N. (2015) Application of Feldespar and Hornblende Composition to Investigate the Nature and Thermobarometry Aftabrou Pluton, Northwest Uroumieh-Dokhtar Magmatic Belt, Iran. Journal of Biodiversity and Environmental Science, 6, 609-662.

[12] Wilkinson, J.J. (2001) Fluid Inclusions in Hydrothermal Ore Deposits. Lithos, 55, 229-272.

[13] Bodnar, R.J. (1993) Revised Equation and Table for Determining the Freezing Point Depression of H2O-NaCl Solutions. Geochimica et Cosmochimica Acta, 57, 683 684.

[14] Sterner, S.M., Hall, D.L. and Bodnar, R.J. (1988) Synthetic Fluid Inclusions. V. Solubility Relations in the System $\mathrm{NaCl}-\mathrm{KCl}-\mathrm{H}_{2} \mathrm{O}$ under Vapor-Saturated Conditions. Geochimica et Cosmochimica Acta, 52, 989-1005.

[15] Shepherd, T., Rankin, A.H. and ALderton, D.H.M. (1985) A Practical Guide to Fluid Inclusion Studies. Blackie, Glasgow; Chapman and Hall, New York, 239.

[16] Barnes, H.L. (1979) Solubility of Ore Minerals. In: Barnes, H.L., Ed., Geochemistry of Hydrothermal Ore Deposits, Wiley, Hoboken, 404-460.

[17] Roedder, E. (1984) Fluid Inclusion. In: Ribbe, P.H., Ed., Review in Mineralogy, Vol. 12, Mineralogical Society of America, Washington DC.

[18] Davidson, E., Neepstand, D.C., Yoko Ishid, F. and Brando, P. (2008) Effects of an Experimental Drought and Recovery on Soil Emissions of Carbon Dioxide, Methane, Nitrous Oxide.

[19] Baker, D.R. (1998) Granitic Melt Viscosity and Dike Formation. Journal of Structural Geology, 20, 1395-1404.

[20] Barton, M.D. and Johnson, D.A. (1996) Evaporitic Source Model for Igneous-Related Fe Oxide-(REE-Cu-Au-U) Mineralization. Geology, 24, 259-262. https://doi.org/10.1130/0091-7613(1996)024<0259:ESMFIR>2.3.CO;2

[21] Williams, P., Barton, D., Johnson, A., Fontbote, L., De Haller, A., Mark, G.H.S., Oliver, N. and Marschik, R. (2005) Iron Oxide Copper-Gold Deposits: Geology, Space-Time Distribution, and Possible Modes of Origin. Society of Economic Geologists, Inc., 371-405.

[22] Marschik, R. (2011) Chilean IOCG Deposits the Candelaria-Punta del Cobre and Mantoverde Systems. Let's Talk Ore Deposits 11 th SGA Biennial Meeting Antofagasta, Chile, September 2011.

[23] Sillitoe, R.H. and Burrows, D.R. (2002) New Field Evidence Bearing on the Origin of the El Laco Magnetite Deposit, Northern Chile. Economic Geology, 97, 1101 1109.

[24] Corriveau, L. (2007) Fe Oxide Copper-Gold Deposits: A Canadian Perspective. In: Goodfellow, W.D., Ed., Mineral Deposits of Canada: A Synthesis of Major DepositTypes, District Metallogeny, the Evolution of Geological Provinces, and Exploration Methods, Special Publication 5, Mineral Deposits Division, Geological Association of Canada. 
[25] Kreiner, D.C. and Barton, M.D. (2011) High-Level Alteration in Iron-Oxide(-Cu$\mathrm{Au}$ ) (IOCG) Vein Systems, Examples near Copiapó, Chile. 11th SGA Biennial Meeting Let's Talk Ore Deposits.

[26] Pirajno, F., Hocking, R.M., Reddy, S.M. and Jones, J.A. (2009) A Review of the Geology and Geodynamic Evolution of the Palaeoproterozoic Earaheedy Basin, Western Australia. Earth-Science Reviews, 94, 39-77.

Submit or recommend next manuscript to SCIRP and we will provide best service for you:

Accepting pre-submission inquiries through Email, Facebook, LinkedIn, Twitter, etc. A wide selection of journals (inclusive of 9 subjects, more than 200 journals)

Providing 24-hour high-quality service

User-friendly online submission system

Fair and swift peer-review system

Efficient typesetting and proofreading procedure

Display of the result of downloads and visits, as well as the number of cited articles

Maximum dissemination of your research work

Submit your manuscript at: http://papersubmission.scirp.org/

Or contact ojg@scirp.org 